\section{News reports of bullying-related fatal and nonfatal injuries in the Americas}

\author{
Jorge Carlos Srabstein ${ }^{1}$
}

Suggested citation: Srabstein JC. News reports of bullyingrelated fatal and nonfatal injuries in the Americas. Rev Panam Salud Publica. 2013;33(5):378-82.

\section{SYNOPSIS}

Bullying is a multifaceted and injurious form of maltreatment, prevalent across social settings and around the globe. Victims and perpetrators of bullying are at significant risk of suffering from an array of morbidity and dying young due to accidental injuries, suicide, and homicide. This study reviews news reports of nonfatal and fatal injuries linked to bullying throughout the Western Hemisphere during 12 months. News reports, obtained through a Google search, of episodes of fatal and nonfatal injuries related to school bullying and violence from July 2011 through June 2012 that affected children and adolescents (ages 5 to 19 years) throughout the Americas were analyzed. News reports were found of 82 cases of bullying-related fatal and nonfatal injuries, occurring in one year, across 24 countries and dependent territories in the Western Hemisphere, which have a combined total youth population of 225.5 million children and adolescents ages 5 to 19 years. Ninety-seven percent of the victims were between 10 and 19 years old; $60 \%$ of them were below age 15, with a male/female ratio of 2:1. News reports of fatal and nonfatal injurious events related to bullying and affecting children and adolescents in the Americas in one year represent the tip of the public health iceberg composing the unknown magnitude of injuries associated with this type of maltreatment. Data on the magnitude of mortality linked to bullying, which would be of the essence in developing public health policies for its prevention, have not been documented.

Key words: bullying; wounds and injuries; suicide; homicide; news; adolescent behavior; Americas.

\footnotetext{
${ }^{1}$ Clinic for Health Problems Related to Bullying, Psychiatry and Behavioral Sciences, Children's National Medical Center, Rockville, Maryland, United States of America. Send correspondence to: Jorge Carlos Srabstein, jsrabste@cnmc.org
}

There is an evolving understanding that bullying is a multifaceted and injurious psychosocial stressor that is prevalent across social settings, along the lifespan, and around the world (1-3). The notion of bullying encompasses physical aggression (hitting, pushing, punching, and kicking), verbal harassment (threatening, teasing, name calling, and making faces or dirty gestures), and indirect or relational mistreatment (ignoring someone or excluding him or her on purpose) (4). Daring a person to perform a dangerous, illegal, or inappropriate act under the threat of losing approval or of not being liked or loved should also be considered a form of bullying (4).

Nearly all studies on bullying are based on the notion that this subtype of aggression is a negative action to which somebody is exposed-intentionally and repeatedly-over time (5). From a health perspective, it is difficult to verify intentionality; yet, the victim is affected even if the aggression is not committed on purpose (4). Furthermore, the notion that bullying needs to be repetitive and over time is perhaps in contradiction to the clinical reality about its ill effects, as one episode of bullying may be sufficient to cause significant emotional or physical harm (4). Across cultures, we can find that the concept of bullying has also been conveyed by other terms like violence, victimization, maltreatment, abuse, intimidation, and harassment (6).

Students who are bullied or who bully others are at significantly higher risk than their uninvolved peers of suffering from a wide spectrum of physical and emotional symptoms, including depression, irritability, anxiety, sleeping difficulties, headaches, and stomachaches occurring almost daily $(7,8)$. Furthermore, an increasing number of studies document that bullying-related morbidity includes serious problems such as episodes of running away, alcohol and drug abuse, and, above all, suicidal behavior and self-inflicted or accidental injuries $(9,10)$. Most of all, bullying is linked to premature mortality due to suicide, homicide, and accidental injuries (11). Data on the magnitude of mortality linked to bullying, which would be of the essence in developing public health policies for its prevention, have not been documented. In the meantime, health professionals and the public in general may begin to be aware of the critical public health risks linked to bullying through news of injurious and lethal incidents of this type of maltreatment and abuse.

The purpose of this study is to examine news coverage of fatal and nonfatal injurious events related to bullying and affecting children and adolescents in the Americas from July 2011 through June 2012. 


\section{METHODS}

\section{News coverage of fatal and nonfatal bullying- related injuries}

This study examined, by country or dependent territory in the Americas, nonduplicated news of fatal and nonfatal injurious events related to bullying or violence from July 2011 through June 2012 that affected children and adolescents (ages 5-19 years).

\section{Country or dependent territory}

The study included all the independent countries and dependent territories represented by the Pan American Health Organization (12).

\section{Number of children and adolescents ages 5-19}

The number of news-reported cases of bullyingrelated fatal and nonfatal injuries was examined within the context of the population (ages 5-19) living in the countries and dependent territories of the Americas (13).

\section{Nonfatal or fatal injurious events related to school bullying or violence}

News-reported incidents related to school bullying or violence resulting in either a nonfatal, physical, or emotional injury that required medical care or in a death by injury due to accident, suicide, or homicide were included in the study. The age of the student needed to be reported in order to be included.

\section{News reports}

The news reports were obtained through an inquiry conducted in country-specific Google search engines (14), under "news," and using the terms "school bullying" and "school violence" and their respective terminology in Spanish, Portuguese, French, and Dutch. The search comprised the period from July 1, 2011, through June 30, 2012. Each search, by country, led to a series of headlines with hyperlinks to a complete or partial published article, commentary, or editorial. Each piece was reviewed to ascertain whether it referred to an episode of bullying or violence causing a fatal or nonfatal injury to a child or adolescent. For inclusion in this study, a published story was required to have documented the name of the victim or the school, age, gender, date of occurrence, location, and information indicating that an injury was allegedly linked to bullying or violence. This information was necessary to avoid entries of different stories pertaining to the same event.

\section{Google News}

"Google News is a computer-generated news site that aggregates headlines from more than 50000 news sources worldwide, groups similar stories together, and displays them according to each reader's interests" (15). The articles and multimedia content are selected and ranked by computers that evaluate, among other factors, how often and where a story appears online. This search engine provides links to headlines of one or more articles for each story, allowing one to select the article that provides the best account of the story. The headlines are selected entirely by computer algorithms based on factors like how often and where a story appears online (15).

\section{Translation Support}

Google Translate (16) was used in reviewing all news stories written in Dutch and sometimes to support the reading of news in Portuguese and French. Google Translate is a free online machine translation that provides instant interpretation of words, phrases, and webpages in 64 languages.

\section{Number of fatal injurious events}

The number of fatal events is expressed as the average number per year of homicide or suicide deaths affecting children and adolescents (ages 5-19) occurring in the Americas from 1995 through 2008 (17).

\section{Frequency of news-reported fatal injuries related to school bullying and violence}

This rate is based on the number of cases of fatal injuries (suicides and homicides) linked to bullying, reported in the news, and affecting children and adolescents (ages 5-19) per country in one year per total number of suicides and homicides in one year in the same country.

\section{RESULTS}

The study located 82 news-reported cases of fatal and nonfatal youth injuries related to bullying or violence occurring in one year across 24 countries and dependent territories in the Western Hemisphere, which have a combined total youth population of 225.5 million children and adolescents ages 5-19.

\section{Reports of bullying-related nonfatal injurious events}

There were reports of 47 bullying-related nonfatal injurious events occurring in 19 countries and dependent territories in the preceding 12 months (Table 1) (see supplementary material). Ninety-six percent of the victims were between 10 and 19 years of age and $62 \%$ of them were males. Sixty percent of the injuries were caused by students being hit, punched, kicked, or beaten, leading to a wide range of lesions, including head and cervical trauma, nasal fractures, and genital injuries. An additional $20 \%$ of the injuries were caused by stabbing. 
TABLE 1. News-reported cases of bullying-related nonfatal injuries in the Americas, July 2011 to June 2012

\begin{tabular}{|c|c|c|c|c|c|c|}
\hline \multirow{2}{*}{$\begin{array}{l}\text { Country, } \\
\text { dependent } \\
\text { territory, or } \\
\text { province }\end{array}$} & \multicolumn{2}{|c|}{$\begin{array}{c}\text { Ages } \\
\text { 5-9 years }\end{array}$} & \multicolumn{2}{|c|}{$\begin{array}{c}\text { Ages } \\
10-14 \text { years }\end{array}$} & \multicolumn{2}{|c|}{$\begin{array}{c}\text { Ages } \\
15-19 \text { years }\end{array}$} \\
\hline & Male & Female & Male & Female & Male & Female \\
\hline \multicolumn{7}{|l|}{ Antigua and } \\
\hline Barbuda & 0 & 0 & 0 & 0 & 2 & 0 \\
\hline Argentina & 1 & 0 & 2 & 4 & 5 & 1 \\
\hline Barbados & 1 & 0 & 0 & 0 & 0 & 0 \\
\hline Belize & 0 & 0 & 0 & 0 & 1 & 0 \\
\hline Brazil & 0 & 0 & 1 & 2 & 0 & 1 \\
\hline Canada & 0 & 0 & 1 & 0 & 0 & 0 \\
\hline Chile & 0 & 0 & 1 & 0 & 0 & 1 \\
\hline Colombia & 0 & 0 & 1 & 0 & 0 & 0 \\
\hline Costa Rica & 0 & 0 & 1 & 1 & 0 & 0 \\
\hline Guadalupe & 0 & 0 & 1 & 0 & 0 & 0 \\
\hline Guatemala & 0 & 0 & 0 & 1 & 0 & 0 \\
\hline Jamaica & 0 & 0 & 0 & 0 & 1 & 0 \\
\hline Mexico & 0 & 0 & 1 & 1 & 0 & 0 \\
\hline Montserrat & 0 & 0 & 1 & 0 & 0 & 0 \\
\hline Panama & 0 & 0 & 1 & 2 & 0 & 0 \\
\hline Paraguay & 0 & 0 & 0 & 1 & 0 & 2 \\
\hline Peru & 0 & 0 & 3 & 0 & 0 & 0 \\
\hline \multicolumn{7}{|l|}{ Trinidad and } \\
\hline Tobago & 0 & 0 & 3 & 0 & 0 & 0 \\
\hline \multicolumn{7}{|l|}{ United States } \\
\hline of America & 0 & 0 & 0 & 0 & 2 & 0 \\
\hline Total & 2 & 0 & 17 & 12 & 11 & 5 \\
\hline
\end{tabular}

\section{Reports of bullying-related fatal injurious events}

Suicides. In one year, there were news reports of 17 cases of bullying-related suicides occurring in six countries in the Western Hemisphere (Table 2) (see supplementary material). Sixty-five percent of the victims were males between 10 and 14 years of age. These news reports represent a very small fraction $(1 / 232)$ of the 3949 suicides per year among children and adolescents (ages 5-19) in the countries and dependent territories of the Americas (17).

Homicides. At least 18 homicides of adolescent students in 9 countries in the Western Hemisphere have been reported in the news for the past year (Table 3) (see supplementary material). They represent a minor portion (1/818) of the 14725 homicides of juveniles in an average year across the Americas (17).

TABLE 2. News-reported cases of bullying-related suicide deaths in the Americas, July 2011 to June 2012

\begin{tabular}{|c|c|c|c|c|c|c|}
\hline \multirow[b]{2}{*}{ Country } & \multicolumn{2}{|c|}{$\begin{array}{c}\text { Ages } \\
5-9 \text { years }\end{array}$} & \multicolumn{2}{|c|}{$\begin{array}{c}\text { Ages } \\
10-14 \text { years }\end{array}$} & \multicolumn{2}{|c|}{$\begin{array}{c}\text { Ages } \\
15-19 \text { years }\end{array}$} \\
\hline & Male & Female & Male & Female & Male & Female \\
\hline Argentina & 0 & 0 & 1 & 0 & 0 & 0 \\
\hline Brazil & 0 & 0 & 1 & 0 & 0 & 0 \\
\hline Canada & 0 & 0 & 1 & 0 & 1 & 1 \\
\hline Peru & 0 & 0 & 1 & 1 & 0 & 0 \\
\hline \multicolumn{7}{|l|}{ Trinidad and } \\
\hline Tobago & 0 & 0 & 0 & 0 & 1 & 0 \\
\hline \multicolumn{7}{|l|}{ United States } \\
\hline of America & 0 & 0 & 4 & 2 & 1 & 2 \\
\hline Total & 0 & 0 & 8 & 3 & 3 & 3 \\
\hline
\end{tabular}

TABLE 3. News-reported cases of bullying-related homicide deaths in the Americas, July 2011 to June 2012

\begin{tabular}{|c|c|c|c|c|c|c|}
\hline \multirow[b]{2}{*}{ Country } & \multicolumn{2}{|c|}{$\begin{array}{c}\text { Ages } \\
\text { 5-9 years }\end{array}$} & \multicolumn{2}{|c|}{$\begin{array}{c}\text { Ages 10-14 } \\
\text { years }\end{array}$} & \multicolumn{2}{|c|}{$\begin{array}{c}\text { Ages } 15-19 \\
\text { years }\end{array}$} \\
\hline & Male & Female & Male & Female & Male & Female \\
\hline Colombia & 0 & 0 & 1 & 0 & 0 & 0 \\
\hline El Salvador & 0 & 0 & 0 & 3 & 2 & 1 \\
\hline Guatemala & 0 & 0 & 1 & 0 & 0 & 0 \\
\hline Guyana & 0 & 0 & 2 & 0 & 0 & 0 \\
\hline Nicaragua & 0 & 0 & 0 & 0 & 1 & 0 \\
\hline Peru & 0 & 0 & 0 & 0 & 1 & 0 \\
\hline $\begin{array}{c}\text { United States } \\
\text { of America }\end{array}$ & 0 & 1 & 0 & 0 & 3 & 1 \\
\hline Uruguay & 0 & 0 & 0 & 0 & 1 & 0 \\
\hline Venezuela & 0 & 0 & 1 & 0 & 0 & 0 \\
\hline Total & 0 & 0 & 5 & 3 & 8 & 2 \\
\hline
\end{tabular}

\section{DISCUSSION}

This study does not aim to determine the epidemiology of bullying-related injury morbidity and mortality in the Western Hemisphere but rather aims to highlight the tip of this public health iceberg as manifested through the lens of news coverage. It is through the selected information about these nearfatal and fatal events that the public in general and policy makers in particular may become more aware of the nature and toxicity of bullying. It has been suggested that (18) "the perceived newsworthiness of a violent event strongly influences a media organization's decision whether or not to report it." The selectiveness of news in part accounts for the geographic disparity in the source of these reports (only 30\% of Western Hemisphere countries published news about bullying-related deaths). Furthermore, there is a huge variance between the 35 news-reported bullyingrelated episodes of suicides and homicides and the 18674 cases of juvenile violent deaths per year that are estimated to occur in the Americas (17).

News reports of 82 cases of fatal and nonfatal youth injuries related to bullying that occurred in one year among $97 \%$ of children and adolescents in the Americas, living in $50 \%$ of its countries and dependent territories, may not constitute enough evidence to raise a red flag among public health experts and policy makers. Nevertheless, they can serve as a catalyst to generate debate about what is known, what can be estimated, and what should be determined about the magnitude of bullying-related morbidity and mortality on the continent.

Based on analysis of data from a health survey of a large national representative sample of adolescents in the United States of America, it has been documented that $3 \%$ to $4 \%$ of students in grades 6-10 suffer from a cluster of frequently occurring physical and emotional symptoms associated with their participation in bullying and hurt themselves or others on purpose (19). Similar statistics are not available for the rest of the Americas, but based on numbers of prevalence for the United States, it can be projected that 6.9 to 9.2 million adolescents living 
in the Americas may suffer from frequent depression, irritability, anxiety, insomnia, headaches, or stomachaches linked to their participation in bullying as victims or perpetrators and tend to intentionally hurt themselves or others.

Based on the notion of bullying that includes all types of aggression, it can be construed that every injury due to a physical assault is associated with bullying. In fact, it can be argued that part of the incidence of bullying-related mortality in the Americas is already known to consist of at least 6 episodes of homicide per 100000 children and adolescents ages 5-19. What percent of the 2 suicidal deaths per 100000 children and adolescents is linked to bullying remains to be determined.

Bullying has been significantly associated with accidental injuries $(9,20)$, probably caused by inattention of the victim, who is preoccupied by the mistreatment or is running away from the perpetrators.

There are approximately 8 accidental deaths in the Americas per year per 100000 children and adolescents (17). It is not known how many of these fatal injuries are linked to bullying.

In order to establish the incidence of bullyingrelated fatal and nonfatal injuries, it is important for public health policies to promote:

- Development of national systems to gather epidemiologic data about nonfatal and fatal injuries affecting children and adolescents treated in outpatient departments,

- Detection of participation in bullying behaviors as a victim or as a perpetrator in all children and adolescents who suffer nonfatal self-inflicted or accidental injuries, and

- Inclusion of information about participation in bullying as a victim or as a perpetrator on all death certificates of children and adolescents who died of self-inflicted or accidental injuries.

Preventive policies (21-23) should advance concerted and coordinated initiatives by health professionals, educators, community agencies, and families to develop plans that deal with:

- Promoting public awareness about the nature, toxicity, and prevention of bullying;

- Developing safe schools and other social environments through programs that enhance mutual respect, sensitivity and support of others, tolerance of diversity, and disapproval of all forms of bullying, mistreatment, and abuse;

- Detecting ongoing incidents of bullying;

- Reporting incidents of bullying to school authorities as a critical public health tool;

- Intervening through school nurses, counselors, and other health professionals to protect and support students who are being bullied as well as counseling perpetrators about the harm they inflict and to promote respect, empathy, tolerance, and sensitivity to others; and
- Medically evaluating and treating victims and perpetrators who experience physical or psychological morbidity due to bullying.

\section{Limitations of this study}

This study focused only on the data available in all the news reports included in the analysis (location, date, age and gender of the victim, form of trauma, and type of injury). Other details pertaining to the causes and circumstances (i.e., what led to the episode, how it evolved) in many cases were not available and could not be meaningfully analyzed.

The methodology of this study may have derived advantages from using Google News as a search tool in finding stories compared with fairly similar research (11) that employed a traditional digital news archive such as LexisNexis Academic (24). A previous comparison of both news search tools showed that LexisNexis failed to spot $50 \%$ or more of stories appearing in major newspapers because of wire-service blind spots (25).

In the design of this study, it was understood that text translation generated by machines will have limitations. Google Translate was chosen as a support tool for this research as it has been shown to rate highest on translating sentences with formal register; lexical ambiguity; phrasal verbs; and grammar compared with nine other online machine translators, which are available on the Internet and free of charge to the general public. In the same context, Google Translate was outperformed in the interpretation of idioms (26).

\section{Conclusions}

News reports of fatal and nonfatal injurious events related to bullying and affecting children and adolescents in the Americas in one year represent the tip of the public health iceberg composing the unknown magnitude of injuries associated with this type of maltreatment.

Data on the magnitude of mortality linked to bullying, which would be of the essence in developing public health policies for its prevention, have not been documented.

\section{SINOPSIS}

\section{Reportajes informativos sobre lesiones mortales y no mortales relacionadas con la intimidación en la Región de las Américas}

La intimidación es una forma multifacética y lesiva de maltrato, prevalente en diferentes entornos sociales y en todo el mundo. Las víctimas y los autores de la intimidación están sometidos a un importante riesgo de padecer varias enfermedades y de morir durante la juventud como consecuencia de lesiones accidentales, suicidios y homicidios. Este estudio analiza los reportajes informativos sobre lesiones mortales y no mortales vinculadas a la intimidación en todo el continente americano durante 12 meses. Se analizaron los 
reportajes informativos, obtenidos mediante una búsqueda de Google, de episodios de lesiones mortales y no mortales relacionadas con casos de intimidación y violencia escolares, desde julio del 2011 a junio del 2012, que habian afectado a niños y adolescentes (de 5 a 19 años) en la Región de las Américas. Se encontraron 82 reportajes informativos de casos de lesiones mortales y no mortales relacionadas con la intimidación que habían ocurrido en un año en 24 países $y$ territorios del continente americano, que en total alberga una población juvenil combinada de 225,5 millones de niños $y$ adolescentes de 5 a 19 años de edad. El 97\% de las víctimas tenian entre 10 y 19 años de edad; $60 \%$ eran menores de 15 años, y la proporción varones/mujeres era de 2:1. Los reportajes informativos sobre sucesos lesivos mortales y no mortales relacionados con la intimidación y que afectan a niños y adolescentes de la Región de las Américas en un año representa la punta del iceberg de salud pública de magnitud desconocida de las lesiones asociadas con este tipo de maltrato. No existen datos verificados sobre la magnitud de la mortalidad vinculada a la intimidación. Estos datos serían de suma importancia para la elaboración de políticas de salud pública dirigidas a su prevención.

Palabras clave: acoso escolar; heridas y traumatismos; suicidio; homicidio; noticias; conducta del adolescente; Américas.

\section{REFERENCIAS}

1. Srabstein JC, Leventhal BL. Prevention of bullying-related morbidity and mortality: a call for public health policies. [Editorial]. Bull World Health Organ. 2010;88(6):403. Available from: http:/ / www.who.int/bulletin/volumes / 88/6/10-077123/en/index. html PMID:20539848

2. Due P, Holstein BE, Soc MS. Bullying victimization among 13 to 15 -yearold school children: results from two comparative studies in 66 countries and regions. Int J Adolesc Med Health 2008;20(2):209-21.

3. Srabstein JC. Be aware of bullying: a critical public health responsibility. Virtual Mentor. 2009;11(2):173-7. http:/ / virtualmentor.ama-assn. org/2009/02/oped1-0902.html

4. Srabstein JC. The prevention of bullying: a whole school and community model. In: Shute RH, Slee PT, MurrayHarvey R, Dix KL, eds. Mental health and wellbeing: educational perspectives. Adelaide: Shannon Research Press; 2011. Pp. 297-305.

5. Olweus, D. Bullying at school: what we know and what we can do. Oxford: Blackwell; 1993. P. 9.

6. Smith PK, Monks CP. Concepts of bullying: developmental and cultural aspects. Int J Adolesc Med Health. 2008;20(2):101-12.

7. Srabstein JC, McCarter RJ, Shao C, Huang ZJ. Morbidities associated with bullying behaviors in adolescents. School based study of American adolescents. Int J Adolesc Med Health. 2006;18(4):587-96.

8. Due P, Holstein BE, Lynch J, Diderichsen F, Gabhain SN, Scheidt $\mathrm{P}$, et al. Bullying and symptoms among school-aged children: international comparative cross sectional study in 28 countries. Eur J Public Health. 2005;15(2):128-32. Available from: http://eurpub.oxfordjourn als.org/content/15/2/128.long PMID:15755782

9. Srabstein J, Piazza T. Public health, safety and educational risks associated with bullying behaviors in American adolescents. Int J Adolesc Med Health. 2008;20(2):223-33.
10. Brunstein Klomek A, Sourander A, Gould M. The association of suicide and bullying in childhood to young adulthood: a review of cross-sectional and longitudinal research findings. Can J Psychiatry. 2010;55(5):282-8.

11. Srabstein J. Deaths linked to bullying and hazing. Int J Adolesc Med Health. 2008;20(2):235-9.

12. Pan American Health OrganizationWorld Health Organization. Home page. Washington, D.C.: PAHO-WHO; 2012. Available from: http://new. paho.org/index.php Accessed 7 May 2013.

13. United States Census Bureau. International programs, international data base, population by single year age groups, by country. Washington, D.C.: United States Census Bureau; 2012 Available from: http://www.census.gov/pop ulation/international/data/idb/ informationGateway.php Accessed 7 May 2013.

14. Google Search Engine. Language/ country specific Google Search Engines. Available from: http://www.aska pache.com/google/languagecoun try-specific-google-search-engines. html Accessed 7 May 2013.

15. About Google. Available from: Newshttp://support.google.com/news/bin/ answer.py?hl=en\&answer $=106259 \&$ top ic $=2428790 \& c t x=$ topic Accessed 7 May 2013.

16. GoogleTranslate. Availablefrom:http:// translate.google.com $/$ ?hl=en\&tab= wT Accessed 7 May 2013.

17. Organización Panamericana de la Salud. Causas principales de mortalidad en las Américas, Sistema Regional de Mortalidad, 2012. Washington, D.C.: OPS; 2012. Available from: http://ais.paho.org/ phip/viz/mort_causasprincipales lt_oms.asp Accessed 7 May 2013.

18. Wintemute GJ, Claire BE, McHenry V, Wright MA. Epidemiology and clinical aspects of stray bullet shootings in the United States. J Trauma Acute Care Surg. 2012;73(1):215-23.

19. Srabstein J, Piazza T. Is there a syndrome of bullying? Int J Adolesc Med Health. 2012;24(1):91-6.
20. Laflamme L, Engström K, Möller J, Alldahl M, Hallqvist J. Bullying in the school environment: an injury risk factor? Acta Psychiatr Scand Suppl. 2002; (412):20-5.

21. American Psychiatric Association. Joint AACAP and APA position statement on prevention of bullying-related morbidity and mortality. Arlington, Virginia: American Psychiatric Association; 2011. Available from: http://www.aacap. org/cs/root/policy_statements/policy_statement_prevention_of_bullying_related_morbidity_and_mortality Accessed 7 May 2013.

22. Srabstein J. Testimony before United States House Education and Labor Committee, Subcommittee on Healthy Families and Communities, Ensuring Student Cyber Safety, June 24, 2010 Available from: http://www.child rensnational.org/files/PDF/advo cacy/OnCapitolHill/testimonyoncy berbullyingsrabstein.pdf Accessed 7 May 2013.

23. Srabstein J, Joshi P, Due P, Wright J, Leventhal B, Merrick J, et al. Prevention of public health risks linked to bullying: a need for a whole community approach. Int J Adolesc Med Health. 2008;20(2):185-99.

24. LexisNexis Academic. LexisNexis home page. Available from: http://www. lexisnexis.com/en-us/products / lexisnexis-academic.page Accessed 7 May 2013

25. Weaver DA, Bimber B. Finding news stories: a comparison of searches using LexisNexis and Google News. Journal Mass Commun Q. 2008;85(3):515-30.

26. Hampshire S, Porta Salvia C. Translation and the Internet: evaluating the quality of free online machine translators. Quaderns Rev Trad. 2010;17:197209.

Manuscript received on 30 September 2012. Revised version accepted for publication on 5 April 2013. 